\title{
Analyzing Financial Insufficiency of Households in Turkey with Multivariate Probit Model
}

\author{
Türkiye'de Hanehalklarının Finansal Yetersizliğinin Multivariate Probit Model \\ ile Analizi
}

Çiler SIGEZE ${ }^{1}$

Mehmet Sedat UĞUR²

\begin{abstract}
Permanent or particular financial insufficiencies of households cause crucial interruptions on compulsory payments of households. In this study, the determining factors of financial insufficiency of 11918 households that surveyed in TurkStat's Survey of Income and Living Conditions (SILC) 2012 are analyzed. The financial insufficiency of households can be denoted by several indicators. The responses of household head for three questions on financial conditions of household in survey are treated as indicators for financial insufficiency. Multivariate Probit Model is used to determine the effects of the properties of household head and households as independent variables on three dependent variables about financial conditions and to estimate these models simultaneously. The findings show that household size, being a tenant, changing the job, being unemployment but looking for a job and being chronic illness for household head have positive, income, being a female and being a graduate from university or a higher degree for household head have negative effects on each financial insufficiency indicators.
\end{abstract}

Keywords: Multivariate probit model, financial insufficiency, households, Turkey https://orcid.org/0000-0001-5329-5066

https://orcid.org/0000-0002-2562-5299

\section{ÖZET}

Hanelerin zaman içerisinde sürekli ya da kısmı zamanlı olarak ekonomik anlamda sıkıntıya girmeleri yani finansal durumlarının yetersiz olması hanelerin zorunlu ödemelerinde aksaklıklar meydana getirebilmektedir. Bu çalışmada TÜiK 2012 yılı Gelir ve Yaşam Koşulları Araştırması (GYKA)'nda yer alan 11918 hanenin finansal yetersizliğinin belirleyicileri analiz edilmiştir. Hanelerin finansal yetersizliği çeşitli göstergelerle ifade edilebilmektedir. Çalışmada hanehalkı reisinin, ankette yer alan hanelerin ekonomik durumlarına ilişkin üç soruya verdiği yanıtlar finansal yetersizliğinin birer göstergesi olarak ele alınmaktadır. Hanelerin ekonomik durumları üzerine bilgi sağlayan üç bağımlı değişken için hanehalkı reisi ve hanenin özelliklerinin etkilerinin belirlenebilmesi ve bu modellerin aynı anda tahmin edilmesi amacıyla çalışmada Multivariate Probit Model kullanılmıştır. Elde edilen bulgular incelendiğinde, her bir finansal yetersizlik göstergesi üzerinde hanehalkı büyüklüğünün, hanehalkının kiracı olmasının, hanehakı reisinin iş değişikliği yapmasının, iş arıyor olmasının ve kronik hasta olmasının pozitif, hanenin gelirinin, hanehalkı reisinin kadın olmasının ve hanehalkı reisinin üniversite ve üstü eğitim düzeyinde olmasının ise negatif etkisi bulunmaktadır.

Anahtar Kelimeler: Multivariate probit model, finansal yetersizlik, hanehalkı, Türkiye

installments, credit card and other debts as well as electricity, water and gas bills are seen as the substantial indicators for their subsistence levels. Also, the incapability to pay these basic payments for many times will cause both the household economy to weaken and 
the individuals to become socially and psychologically distressed.

There are several studies on analyzing economic conditions of individuals or households which are mostly concerned with the poverty status of the relevant units. In general, the logit and the probit models are used to analyze the determinants of the poverty status of households. Financial insufficiency can be seen as an indicator for households that suffering from poverty. Thus, multiple indicators can be used on determining the financial insufficiency of households. In the case where these indicators are set as dependent variables, it is appropriate to use multivariate probit (MVP) model to examine the affects of independent variables on these indicators by considering the correlation between the dependent variables. Using the MVP model makes it possible to analyze whether the units of analysis finance their basic and compulsory payments and to examine the deprivation conditions of households by considering multiple indicators instead of taking a solely income-based indicator.

In this study, we used three financial condition indicators as dependent variables which are generally used as dimensions of subjective wellbeing in the literature, because they include direct responses of households in relevant survey. The paper will start with a brief background study about the relevant theory and literature and this will comprise the following chapter. On third chapter, we will explain the data and methodology used in our analysis by describing multivariate probit model and our data set in brief. The final two chapters will include the findings and the conclusions of the study.

\section{BACKGROUND}

Investigating the living standards of the individuals is a long-concerned issue in economics. These studies are mostly encompassed by poverty studies. But poverty, as a quite complex concept in its nature, has many definitions. Income or expenditure poverty (World Bank, 1990; Ravallion, 1996), lack of basic needs (Streeten, Burki, ul Haq, Hicks \& Stewart, 1981), relative deprivation (Runciman, 1966; Townsend, 1979), lack of capabilities and functionings (Sen, 1985; Nussbaum, 2000), social exclusion (Rodgers, Gore and Figueiredo, 1995; Bhalla and Lapeyre, 1997), human underdevelopment (UNDP, 1990; ul Haq, 1995), multidimensional poverty (Bourguignon \& Chakravarty, 2003; Alkire \& Foster, 2009), vulnerability (Morduch, 1994), ill-being (Brock, 1999) and unsustainability of subsistence levels (Chambers and Conway, 1992) are some of these definitions, among others. One other dimension of poverty is related with life satisfaction and happiness of individuals which is called as subjective wellbeing. Orshansky (1969) defines poverty as a value judgment and for Orshansky, poverty, like beauty, lies in the eye of the beholder. In here, poverty is seen as a subjective concept and related with wellbeing. Subjective wellbeing is defined as judging life positively, often feeling joy and experiencing sadness infrequently. That definition is linked with Diener et al (1997)'s definition, as cited by Veenhoven (2008): "a person is said to have high subjective wellbeing if she/ he experiences life satisfaction and frequent joy, and only infrequently experiences unpleasant emotions such as sadness and anger".

Subjective wellbeing studies are generally related with the concept of happiness in economics. As Veenhoven (1984) noted, overall happiness is synonymous with life satisfaction and subjective wellbeing. Veenhoven (2000) also defines subjective wellbeing as "four qualities of life" by including both inner and outer qualities of life chances and life results. These qualities of life involve the livability of environment, external utility of life, life-ability of person and inner appreciation of life (Veenhoven, 2000). There are other considerable studies in literature which analyze subjective wellbeing (van Praag, 1971; van Praag and Kapteyn, 1973; Easterlin, 1974; Oswald, 1997; Pradhan and Ravallion, 2000; van Praag et al., 2003; among others). Although we accept that general happiness of life includes all dimensions of subjective wellbeing which may include health, leisure and environment satisfaction, among others; we only use financial indicators to determine financial wellbeing of households in this study. Thus, rather using the concept of financial wellbeing, we use the concept of financial insufficiency in our analysis and the analysis mostly concern with the financial domains of life of households.

There are only a few studies for Turkey which are related with our study. One of them is Selim (2008)'s study which investigates life satisfaction and happiness in Turkey by using an ordered logit model, and they found that employment and health status, in particular, exert a strong influence on life satisfaction. Dal and Sevuktekin (2018) also investigate the factors for life satisfaction with ordered logit model by using the Survey of Income and Living Conditions (SILC) 2013 for Turkey. Their findings show that the satisfaction of individuals in financial conditions has the key 
effect on general life satisfaction. This inference shows the priority of financial conditions, among others. To our knowledge, this study is the first attempt in the literature for Turkey using the relevant methodology and data. Çevik and Korkmaz (2014), Eren and AşıCı (2017) and Timur and Akay (2017) are other related studies that investigate subjective wellbeing in Turkey for specific periods.

\section{DATA AND METHODOLOGY}

\subsection{Data And Variables}

We used cross-sectional data set of Turkstat's Survey of Income and Living Conditions (SILC) for 2012. This survey has been annually published since 2006. The size of the sample for our period of analysis is 11918 households. There are some questions in the survey which are asked to the household head and are shown whether the income of household is insufficient. Three of these questions on financial condition of households are as follows: "whether they have the incapability to finance arrears on mortgage, loan repayments or rent payments in the last 12 months", "whether they have the incapability to finance arrears on utility bills in the last 12 months" and "whether they have the incapability to finance arrears on hire purchase installments, credit cards or other loan payments in the last 12 months". The answers are classified as "yes", "no" and "there is no such kind of payment" in the survey. The dependent variables are created as taking on the values of 0 and 1 , where 1 means that the answer of the household head is "yes" and 0 is otherwise. Table 1 shows the basic definitions and descriptive statistics of the variables which are used in the study.

Table 1: Descriptive Statistics

\begin{tabular}{|c|c|c|c|}
\hline Variables & Definition & Mean & Std. Err. \\
\hline \multicolumn{4}{|l|}{ Dependent Variables } \\
\hline Financial condition 1 & $\begin{array}{l}\text { incapability to finance arrears on mortgage, loan repayments } \\
\text { or rent payments in the last } 12 \text { months }\end{array}$ & 0.088 & 0.002 \\
\hline Financial condition 2 & incapability to finance arrears on utility bills in the last 12 months & 0.373 & 0.004 \\
\hline Financial condition 3 & $\begin{array}{l}\text { incapability to finance arrears on hire purchase installments, } \\
\text { credit cards or other loan payments in the last } 12 \text { months }\end{array}$ & 0.265 & 0.004 \\
\hline \multicolumn{4}{|c|}{ Household Head Related Variables } \\
\hline Independent Variables & Definition & Mean & Std. Err. \\
\hline Female & 1 if the household head is female, 0 otherwise & 0.160 & 0.003 \\
\hline Age & The age of the household head & 49.082 & 0.14 \\
\hline Age $^{2}$ & The square of the age of the household head & 2643.391 & 14.808 \\
\hline Chronic illness & 1 if the household head is chronically ill, 0 otherwise & 0.380 & 0.004 \\
\hline SSI (Social Security Institution) & $\begin{array}{l}1 \text { if the household head is registered to social security } \\
\text { institutions in the main job, } 0 \text { otherwise }\end{array}$ & 0.414 & 0.004 \\
\hline Job replacement & $\begin{array}{l}1 \text { if the household head has changed his/her job in the last } 12 \\
\text { months, } 0 \text { otherwise }\end{array}$ & 0.082 & 0.002 \\
\hline \multicolumn{4}{|l|}{ Marital Status } \\
\hline Single & 1 if the household head is single, 0 otherwise & 0.03 & 0.001 \\
\hline Married & 1 if the household head is married, 0 otherwise & 0.823 & 0.003 \\
\hline Widow or divorced (reference) & 1 if the household head is widowed or divorced, 0 otherwise & 0.147 & 0.003 \\
\hline \multicolumn{4}{|l|}{ Education } \\
\hline Illiterate or Literate (reference) & $\begin{array}{l}1 \text { if the household head is illiterate or literate but not a } \\
\text { graduate, } 0 \text { otherwise. }\end{array}$ & 0.164 & 0.003 \\
\hline Primary-Secondary school & $\begin{array}{l}1 \text { if the household head is graduated from primary school or } \\
\text { secondary, vocational secondary or primary education school, } \\
0 \text { otherwise. }\end{array}$ & 0.545 & 0.004 \\
\hline High School & $\begin{array}{l}1 \text { if the household head is graduated from high school, or } \\
\text { vocational or technical high school, } 0 \text { otherwise }\end{array}$ & 0.161 & 0.003 \\
\hline University & $\begin{array}{l}1 \text { if the household is graduated from faculty/university, college } \\
\text { or higher education level, } 0 \text { otherwise }\end{array}$ & 0.13 & 0.003 \\
\hline \multicolumn{4}{|l|}{ Working Situation } \\
\hline Employee & 1 if the household head is employed, 0 otherwise & 0.648 & 0.004 \\
\hline Unemployed (Looking for a job) & 1 if the household head is looking for a job, 0 otherwise & 0.028 & 0.001 \\
\hline
\end{tabular}




\begin{tabular}{|c|c|c|c|}
\hline Retired & 1 if the household head is retired, 0 otherwise & 0.175 & 0.003 \\
\hline Inactive (reference) & $\begin{array}{l}1 \text { if the household head is old, permanently disabled } \\
\text { and/or unfit to work or fulfilling domestic tasks and care } \\
\text { responsibilities, } 0 \text { otherwise }\end{array}$ & 0.149 & 0.003 \\
\hline \multicolumn{4}{|l|}{ Employment Type } \\
\hline Regular & 1 if the household head is a regular employee, 0 otherwise & 0.355 & 0.004 \\
\hline Casual & $\begin{array}{l}1 \text { if the household head is a casual employee or an unpaid } \\
\text { family worker, } 0 \text { otherwise }\end{array}$ & 0.065 & 0.002 \\
\hline Employer & 1 if the household head is an employer, 0 otherwise & 0.038 & 0.001 \\
\hline Self-employed & 1 if the household head is self-employed, 0 otherwise & 0.19 & 0.003 \\
\hline \multicolumn{4}{|c|}{ Household Related Variables } \\
\hline Household size & The size of the household & 3.983 & 0.019 \\
\hline Tenant status & 1 if the household is tenant, 0 otherwise & 0.202 & 0.003 \\
\hline Income & The logarithm of the income of households. & 9.893 & 0.006 \\
\hline
\end{tabular}

We classified our variables as two main categories which one is related directly to the household head and the other one is concerned with the households as a whole. All variables which are related with household head are categorical and dummy variables with the exception of age variable. Since we want to investigate whether female headed households are more vulnerable to financial insufficiency, we accept females as our primal gender variable.

One other important group of variables is marital status of the household head. In here, reference variable is widowed or divorced individuals. Again, we know that educational level and working situation of household head is a key component on determining the welfare of household. Also, we define some other independent variables which are seen as determining factors for financial insufficiency such as household size.

Table 1 shows that the $8.8 \%$ of households in the survey do not have the capability to finance arrears on mortgage, loan repayments or rent payments in the last 12 months. On the other hand, $37.3 \%$ of households do not have the capability to finance arrears on utility bills in the last 12 months. Finally, $26.5 \%$ of the households stated that they do not have the capability to finance arrears on hire purchase installments, credit cards or other loan payments in the last 12 months. Thus, it appears that the households suffer mostly in paying utility bills which includes the basic needs of the individuals such as electricity, water and gas.

\subsection{Multivariate Probit Model}

The multivariate probit (MVP) model denotes the influence of the set of independent variables on dependent variables by allowing the unobserved error terms to be freely correlated (Golob and Regan, 2002; Greene, 2003) which is also one form of a correlated binary response regression model (Castillo-Manzano, 2010). The general specification for M-equation multivariate probit model can be expressed as (Cappellari and Jenkins, 2003);

$$
\begin{aligned}
& y_{i m}^{*}=\beta_{m}{ }^{\prime} X_{i m}+e_{i m} \quad m=1,2, \ldots, M \\
& y_{i m}=1 \text { if } y_{i m}^{*}>0 \text { and } 0 \text { otherwise, }
\end{aligned}
$$

where $e_{i m}$ represents error terms that have multivariate normal distribution with zero mean and variance -covariance matrix $V$ with values 1 on the leading diagonal and correlations $\rho_{j k}=\rho_{k j}$ as off-diagonal elements. We focus on the trivariate probit case in which $\mathrm{M}=3$, then the log likelihood function for a $\mathrm{N}$ sample of observations can be written by;

$$
L=\sum_{i=1}^{N} w_{i} \log \Phi_{3}\left(\mu_{i}, \Omega\right)
$$

where $w_{i}$ is an optional weight for observation $i=1,2, \ldots, N$ and $\Phi_{3}$ is the trivariate standard normal distribution with arguments $\mu_{i}$ and $\Omega . \mu_{i}=\left(K_{i 1} \beta_{1}^{\prime} X_{i 1}, K_{i 2} \beta_{2}^{\prime} X_{i 2}, K_{i 3} \beta_{3}^{\prime} X_{i 3}\right)$. is a constituent of , $K_{i 1}=2 y_{i 1}-1, K_{i 2}=2 y_{i 2}-1$ and $K_{i 3}=2 y_{i 3}-1$ - Here $\Omega$ consists of $\Omega_{i j}=1$ for $j=1,2,3$ and $\Omega_{12}=\Omega_{21}=K_{i 1} K_{i 2} \rho_{21}, \Omega_{13}=\Omega_{31}=K_{i 3} K_{i 1} \rho_{31}, \Omega_{23}=\Omega_{32}=K_{i 3} K_{i 2} \rho_{32}$ (Cappellari and Jenkins, 2003).

MVP models are estimated by using the simulated maximum likelihood method that uses Geweke-Hajivassiliour-Keane (GHK) smooth recursive conditioning simulator procedure to evaluate the multivariate normal distribution. The estimations are made by using STATA (Cappellari and Jenkins, 2003) 14.0 software. 
In the study, we calculated eight joint probabilities corresponding to the eight possible combinations of $\operatorname{successes}\left(y_{i m}=1\right)$ and failures $\left(y_{i m}=0\right)$ in the trivariate case. For example, the possibility that every outcome

$$
\begin{aligned}
& P\left(y_{1}=1, y_{2}=1, y_{3}=1\right)=P\left(e_{1} \leq \beta_{1}^{\prime} X_{1}, e_{2} \leq \beta_{2}^{\prime} X_{2}, e_{3} \leq \beta_{3}^{\prime} X_{3}\right) \\
& =P\left(e_{3} \leq \beta_{3}^{\prime} X_{3} \mid e_{2}<\beta_{2}^{\prime} X_{2}, e_{1}<\beta_{1}^{\prime} X_{1}\right) \times P\left(e_{2}<\beta_{2}^{\prime} X_{2} \mid e_{1}<\beta_{1}^{\prime} X_{1}\right) \times P\left(e_{1}<\beta_{1}^{\prime} X_{1}\right)
\end{aligned}
$$

\section{EMPIRICAL RESULTS}

We estimated a multivariate model with three dependent variables to analyze the determining factors of financial insufficiency of households in the last 12 months. The first model implies the incapability to finance arrears on mortgage, loan repayments or rent payments in the last 12 months that is named as the financial condition 1 . The second model specifies the incapability to finance arrears on utility bills in the is a success with a conditioning upon unobservable variables that are correlated with each other is given by (Cappellari and Jenkins, 2003);

last 12 months that is named as the financial condition 2. Finally, the third model implies the incapability to finance arrears on hire purchase installments, credit cards or other loan payments in the last 12 months that is named as the financial condition 3. Estimation results for the MVP models are shown in table 2 below. The models 1, 2 and 3 respectively show the estimation results for the dependent variables of financial conditions 1,2 and 3 .

\begin{tabular}{|c|c|c|c|c|c|c|}
\hline & \multicolumn{2}{|c|}{ Model 1} & \multicolumn{2}{|c|}{ Model 2} & \multicolumn{2}{|c|}{ Model 3} \\
\hline & Coef. & Std. Err. & Coef. & Std. Err. & Coef. & Std. Err. \\
\hline \multicolumn{7}{|c|}{ Household Head Related Variables } \\
\hline Female & $-0.153^{*}$ & 0.091 & $-0.192^{* * *}$ & 0.056 & $-0.105^{*}$ & 0.057 \\
\hline Age & $0.038^{* * *}$ & 0.011 & $0.020^{* * *}$ & 0.005 & $0.019^{* * *}$ & 0.005 \\
\hline Age $^{2}$ & $-0.0005^{* * *}$ & 0.0001 & $-0.0003^{* * * *}$ & 0.00005 & $-0.0003^{* * *}$ & 0.00005 \\
\hline Chronic illness & $0.155^{* * *}$ & 0.052 & $0.073^{* *}$ & 0.028 & $0.148^{* * *}$ & 0.028 \\
\hline SSI (Social Security Institution) & $-0.124^{*}$ & 0.070 & $-0.159 * * *$ & 0.039 & -0.043 & 0.040 \\
\hline Job replacement & $0.236^{* * *}$ & 0.066 & $0.206^{* * *}$ & 0.045 & $0.267^{* * *}$ & 0.044 \\
\hline Single & -0.016 & 0.097 & $-0.146^{* * *}$ & 0.055 & -0.065 & 0.057 \\
\hline Maried & -0.179 & 0.139 & $-0.198^{* *}$ & 0.091 & $-0.159 *$ & 0.093 \\
\hline \multicolumn{7}{|l|}{ Education } \\
\hline Primary-Secondary school & 0.030 & 0.084 & $-0.128^{* * *}$ & 0.041 & $-0.075^{*}$ & 0.042 \\
\hline High School & -0.127 & 0.100 & $-0.288^{* * *}$ & 0.053 & $-0.178^{* * *}$ & 0.054 \\
\hline University or higher & $-0.396^{* * *}$ & 0.116 & $-0.610^{* * *}$ & 0.064 & $-0.476^{* * *}$ & 0.064 \\
\hline \multicolumn{7}{|l|}{ Working Situation } \\
\hline Employee & 0.265 & 0.515 & 0.475 & 0.350 & 0.237 & 0.357 \\
\hline $\begin{array}{l}\text { Unemployed (looking for a } \\
\text { job) }\end{array}$ & $0.246^{*}$ & 0.131 & $0.247^{* * *}$ & 0.086 & $0.266^{* * *}$ & 0.083 \\
\hline Retired & -0.073 & 0.110 & $-0.242^{* * *}$ & 0.055 & -0.055 & 0.057 \\
\hline \multicolumn{7}{|l|}{ Employment Type } \\
\hline Regular & -0.387 & 0.509 & -0.512 & 0.348 & -0.216 & 0.356 \\
\hline Casual & -.262 & 0.511 & -0.367 & 0.348 & -0.144 & 0.355 \\
\hline Employer & -0.237 & 0.522 & -0.473 & 0.354 & -0.208 & 0.362 \\
\hline Self-employed & -0.384 & 0.509 & -0.413 & 0.348 & -0.177 & 0.355 \\
\hline
\end{tabular}

Table 2: Multivariate Probit Model Coefficient Estimation Results 


\begin{tabular}{|c|c|c|c|c|c|c|}
\hline \multicolumn{7}{|c|}{ Household Related Variables } \\
\hline Household size & $0.045^{* * *}$ & 0.126 & $0.115^{* * *}$ & 0.006 & $0.075^{* * *}$ & 0.006 \\
\hline Tenant status & $2.096^{* * *}$ & 0.051 & $0.067^{* *}$ & 0.032 & $0.199^{* * *}$ & 0.032 \\
\hline Income & $-0.190^{* * *}$ & 0.039 & $-0.360 * * *$ & 0.022 & $-0.197^{* * *}$ & 0.022 \\
\hline Constant & $-1.102^{* *}$ & 0.452 & $2.966^{* * *}$ & 0.237 & $0.947^{* * *}$ & 0.242 \\
\hline \multicolumn{7}{|c|}{ Correlation Coefficient } \\
\hline rho21 & $0.379^{* * *}$ & 0.018 & & & & \\
\hline rho31 & $0.390 * * *$ & 0.019 & & & & \\
\hline rho32 & $0.659^{* * *}$ & 0.010 & & & & \\
\hline Likelihood ratio test & $\operatorname{chi} 2(3)=2674.84$ & & $\mathrm{hi} 2=0.000$ & & & \\
\hline
\end{tabular}

We began with applying the likelihood ratio test to analyze the existence of the relationship between error terms of models and the degree of correlation. The basic $\left(\mathrm{H}_{0}\right)$ hypothesis in this test presents that the correlations between models are equal to zero. If the correlations between models are equal to zero, the models will be independent to each other, and then they can be estimated separately. Table 2 shows that $\mathrm{H}_{0}$ hypothesis is rejected due to the likelihood ratio test. Then, there is a correlation between models and they need to be estimated altogether. So, it is appropriate to use MVP model in the analysis.

According to table 2, coefficients of female, university-related and income variables are statistically significant and negative for all three models. It means that these variables have negative effects for households on having financial insufficiency. Recent studies (Devicenti, 2002; Andriopoulou and Tsakloglou, 2011; Wallelign et al., 2016; Acar and Başlevent, 2014; Dalgıc et al., 2015) also support the result that being a female household head has a negative effect on financial insufficiency of household.

For the variables of educational status of households, we defined "household head is illiterate or literate but not a graduate" variable as a reference variable. According to model 1 , the probability of the incapability to finance arrears on mortgage, loan repayments or rent payments in the last 12 months decreases for only the households who graduated university or higher. The findings of model 2 and model 3 show that the probability of the incapability to finance arrears on utility bills in the last 12 months and the incapability to finance arrears on hire purchase installments, credit cards or other loan payments in the last 12 months decreases as educational level of household head increases. The common literature between educational level and financial status also support that view (Tilak, 1989; Easterlin, 2001; Bourguignon and Chakravarty, 2003).

The coefficients of income variable are negative and statistically significant in all three models, as expected. As income increases, the probability of incapability to finance compulsory payments decreases. It is obvious here that the income is a vital variable on financial conditions of households as it is an important indicator for their subsistence levels.

According to table 2, the coefficients of chronic illness, job replacement, unemployed (looking for a job), household size and tenant status variables are positive and statistically significant. It means that if the household head has a chronic illness, he/she has changed job in the last 12 months, he/she is unemployed but looking for a job or he/she is a tenant, it is probable that he/she will be incapable to finance his/ her compulsory payments. For the household head, having a chronic illness may cause household to have an irregular income which is consequently resulted as incapability to finance their compulsory payments. Similarly, changing the job in the last 12 months leads household to have an irregular income. As a result, the households are unable to cover their compulsory payments at least once in the relevant period. In that case, unemployment insurances may be useful for these households to avert their income volatilities. Increasing household size causes negative effects in financial conditions of households, as expected. Promoting public awareness on family planning by the state and helping the families on child and elderly care may secure households to get rid of financial insufficiency.

Being a tenant has a positive effect on incapability to finance basic payments at least once in all three 
models. But reasonably, the highest coefficient value is seen in model 1 which includes the financial condition variable related to the incapability to finance arrears on mortgage, loan repayments or rent payments in the last 12 months.

One of the remarkable findings of the analysis is that the employment type of the households has no effect on the incapability to finance the relevant payments. It means that being a regular, casual or self-employed worker is not related with relevant financial conditions, according to our models. Furthermore, according to household head who is inactive (old, permanently disabled and/or unfit to work or fulfilling domestic tasks and care responsibilities) in economic lives which is the reference variable, working situation of household as an employee is also statistically insignificant in all three models. Therefore, occupation of the household and his/her status as employed is not solely sufficient for households to make ends meet. This is in fact one other indicator that shows the income of the household also is not solely sufficient at that point. Planning the incomes and expenses well enough to ensure household welfare becomes a crucial issue at that perspective.

In model 2, according to inactive household head variable as reference, working situation of household as retired has negative effect on the probability of the incapability to finance arrears on utility bills in the last 12 months. In that case, being retired means that there is a regular income flow to household and then paying utility bills is delivered as a routine.

For household head, being registered to Social Security Institution (SSI) has a negative effect on incapability to finance relevant payments for model 1 and model 2, but it has no statistically significant effect on model 3.

According to the widowed or divorced household head variable which is the reference variable, being a single and married household head has a negative effect on incapability to finance utility bills in the last 12 months (model 2). Therefore, it is observed that single and married individuals have better financial conditions than the others. Also, being a single household head has a negative effect on incapability to finance arrears on hire purchase installments, credit cards or other loan payments in the last 12 months (model 3). But, marital status of the household head has no statistically significant effect for model 1 .
For all three models, the coefficients of the age of the household head are positive, but the coefficients of the age squared of the household head are negative. This means that the probability of incapability to finance compulsory payments increases as the age of the household head increases; but after the mean age, the probability of incapability to finance these payments decreases as the age of the household head increases. The mean of the household age is found 49 years in this study. Here we can say that the job experience along with the continuity in earnings and savings maintain to finance compulsory payments for the households whose ages are above the mean age.

In addition, we predicted the probability of success for each regression. Table 3 shows the summary statistics about the predicted probability of success for relevant variables:

Table 3: Summary Statistics About The Predicted Probability Of Success

\begin{tabular}{llllll}
\hline Variable & Observation & Mean & Std. Dev. & Min & Max \\
\hline pall1s & 11918 & 0.038 & 0.079 & $1.80 \mathrm{e}-07$ & 0.714 \\
\hline pall0s & 11918 & 0.538 & 0.205 & 0.012 & 0.992 \\
\hline pmargm1 & 11918 & 0.089 & 0.166 & $1.02 \mathrm{e}-06$ & 0.843 \\
\hline pmargm2 & 11918 & 0.370 & 0.185 & 0.002 & 0.982 \\
\hline pmargm3 & 11918 & 0.264 & 0.126 & 0.003 & 0.818 \\
\hline
\end{tabular}

The "pmarg" and "pall" shows predicted marginal success probability for each model and joint probabilities, respectively. The joint probabilities refer to the probability that each binary outcome $=1$ for successes, or that each binary outcome $=0$ for failures, for the each observations of the variables (Cappellari and Jenkins, 2003). The variable of pall1s show the probability of the dependent variable for an observation on taking the value of 1 in each models which present the probability of incapability to finance basic payments of households for all three compulsory financial conditions. The mean value of this probability is around $3 \%$. Lower mean for probability of incapability to finance basic payments of households simultaneously reflects the structure of the dataset. On the other hand, the variable of pallos show the probability of the dependent variable for an observation on taking the value of 0 in each models which present the probability of capability to finance basic payments of households for all three compulsory financial conditions. The mean value of this probability is around $53 \%$ and the maximum value is $99.2 \%$. It indicates that the proba- 
bility to finance all type of compulsory payments for households is quite high.

The "pmarg" specifies the predicted marginal success probability from each model, and the main findings show that the average marginal success probabilities of the models are around $8 \%, 37 \%$ and $26 \%$ respectively. Thus, the model 2 is identified as the most successful model. As a matter of fact, criteria of the maximum values are taken into account; the highest marginal probability of success in the model 2 is higher than the other two models and the value of probability is quite close to 1 .

In general, the findings show that the model 2 is the most successful model in our three models on predicting the incapability to finance relevant payments which are taken as the financial insufficiency indicators of households. It means that the incapability to finance utility bills have a key role on determining the financial insufficiency of households.

\section{CONCLUSION}

This study is aimed to determine whether the households experience financial insufficiency in Turkey by using the data set of TurkStat's SILC 2012 and identify the type of payments for the households that having difficulties to meet when they have financial insufficiency. In that case, we analyzed the determining factors of incapability to finance arrears on mortgage, loan repayments or rent payments, utility bills, hire purchase installments, credit cards or other loan payments in the last 12 months. Because of the dependent variables which present three different payment difficulties are correlated, we used multivariate probit model. Thus, it is important to identify whether the compulsory payments are made and investigate these cases with multiple financial-based indicators rather than using a sole income-based indicator.

The findings of the study show that the main indicator of the financial insufficiency of the households is the incapability to finance utility bills in the last 12 months. Also, being a female household head and faculty or higher-degree graduated household head have a negative effect on incapability to finance compulsory payments in all three models. This means that these variables have positive impacts for households on not having financial insufficiency. Additionally, being chronically ill, changing job in the last 12 months, being unemployed but looking for a job, the size of the household and being a tenant have a positive effect on incapability to finance compulsory payments in all three models. Finally, it is found that being an employee and the employment types do not have any statistically significant effect on the problem of incapability to finance the compulsory payments of the households. Accordingly, the findings show that being an employed household head is not the solely adequate variable itself for the households to make their ends meet. But, the sufficient income flows to households and also decreasing the quantity of payments have a substantial role on welfare of the households.

As a conclusion, the individuals need to endeavor well on planning household economics and the policy-makers have to work quite efficiently on promoting employment and education to individuals, family planning and operating decent social security institutions. 


\section{REFERENCES}

Acar, A. ve Baslevent, C. (2013) "Examination of the Transition of Turkish Households into and out of Poverty between 2007-2010" (No. 5779), EcoMod.

Alkire, S. ve Foster, J. (2009) “Counting and Multidimensional Poverty Measurement" OPHI Working Paper. No. 32. December. Oxford Department of International Development, Queen Elizabeth House (QEH), University of Oxford.

Andriopoulou, E. ve Tsakloglou, P. (2011) "The Determinants of Poverty Transitions in Europe and the Role of Duration Dependence" IZA Discussion Paper No. 5692.

Bhalla, A. ve Lapeyre, F. (1997) "Social Exclusion: Towards an Analytical and Operational Framework" Development and Change, 28: 413-433.

Bourguignon, F. ve Chakravarty, S.R (2003) "The Measurement of Multidimensional Poverty" The Journal of Economic Inequality, 1 (1): 25-49.

Brock, K. (1999) "It's Not Only Wealth That Matters - It's Peace of Mind Too: A Review of Participatory Work on Poverty and Illbeing" Washington: World Bank.

Cappellari, L. ve Jenkins, S. P. (2003) "Multivariate Probit Regression using Simulated Maximum Likelihood" The Stata Journal, 3(3), 278-294.

Castillo-Manzano, J. I. (2010) "Determinants of Commercial Revenues at Airports: Lessons Learned from Spanish Regional Airports" Tourism Management, 31(6), 788-796.

Chambers, R. ve Conway, G. (1992) "Sustainable Rural Livelihoods: Practical Concepts for the 21st Century" IDS Discussion Paper. No. 296. Brighton: IDS.

Çevik, N. K. ve Korkmaz, O. (2014) “Türkiye'de Yaşam Doyumu ve İş Doyumu Arasındaki İlişkinin Iki Değişkenli Sıralı Probit Model Analizi" Ömer Halisdemir Üniversitesi İktisadi ve İari Bilimler Fakültesi Dergisi, 7(1), 126.

Dal, S. ve Sevüktekin, M. (2018) "Türkiye'de Öznel İyi Oluş'un Yaşam Alanları Yaklaşımı İle Ölçülmesi" Uluslararası İktisadi ve İdari İncelemeler Dergisi, 2018: 433-446.

Dalgıç, B., lyyidoğan, P. V. ve Güven, A. (2015) “Yoksulluk ve Yoksulluk Geçişlerinin Belirleyenleri: Türkiye Örneği", Sosyoekonomi, 23(24):51-70.

Devicienti, F. (2002) "Poverty Persistence in Britain: A Multivariate Analysis using the BHPS, 1991-1997" Journal of Economics, 9:307-340.
Diener, E., Suh, E. ve Oishi, S. (1997) "Recent Findings on Subjective Well-being" Indian Journal of Clinical Psychology, 24: 25-41.

Easterlin, R.A. (1974) “Does Economic Growth Improve the Human lot? Some Empirical Evidence" In David, P.A., and Reder, M.W. (eds.). Nations and Households in Economic Growth: Essays in Honor of Moses Abramowitz (pp. 89- 125). Academic Press, NY.

Easterlin, R. A. (2001) "Income and Happiness: Towards a Unified Theory", The Economic Journal, 111(473): 465-484.

Eren, K. A. ve Aşıcl, A. A. (2017) "The Determinants of Happiness in Turkey: Evidence from City Level Data", Journal of Happiness Studies, 18(3): 647-669.

Golob, T. F. ve Regan, A. C. (2002) "Trucking Industry Adoption of Information Technology: A Multivariate Discrete Choice Model", Transportation Research Part C: Emerging Technologies, 10(3): 205-228.

Greene, W. H. (2003) Econometric Analysis, Pearson Education: India.

Morduch, J. (1994) "Poverty and Vulnerability" The American Economic Review, 84(2): 221-225, Papers and Proceedings of the Hundred and Sixth Annual Meeting of the American Economic Association (May).

Nussbaum, M. (2000) Women and Human Development, Cambridge University Press.

Orshansky, M. (1969) "How Poverty is Measured" Monthly Labor Review, 92(2): 37-41.

Oswald, A. J. (1997) "Happiness and Economic Performance" The Economic Journal, 107(445): 1815-1831.

Pradhan, M. ve Ravallion, M. (2000) “Measuring Poverty using Qualitative Perceptions of Consumption Adequacy" Review of Economics and Statistics, 82(3): 462-471.

Ravallion, M. (1996) "Issues in Measuring and Modelling Poverty" The Economic Journal. 106(438): 13281343.

Rodgers, G., Gore, C. ve Figueiredo, J. B. (1995) "Social Exclusion: Rhetoric, Reality, Responses" International Institute for Labour Studies: UNDP.

Runciman, W.G. (1966) "Relative Deprivation and Social Justice", Routledge and Kegan Paul: London.

Selim, S. (2008) "Life Satisfaction and Happiness in Turkey" Social Indicators Research, 88(3):531-562. 
Sen, A. (1985) "Commodities and Capabilities", Amsterdam: Elsevier.

Streeten, P., Burki, S. J., ul Haq, M., Hicks, N. ve Stewart, F. (1981) "First Things First: Meeting Basic Human Needs In The Developing Countries" Washington D. C.: OUP.

Tilak, J. B. (1989) "Education and Its Relation to Economic Growth, Poverty, and Income Distribution: Past Evidence and Further Analysis" World Bank Discussion Paper No.46.

Timur, B. ve Akay, E. Ç.(2017) "Kadın ve Erkeklerin Mutluluğunu Etkileyen Faktörlerin Genelleştirilmiş Sıralı Logit Modeli ile Analizi" Social Sciences Res. Jou., 6(3): 88-105.

Townsend, P. (1979) Poverty in the United Kingdom, University of California Press.

TÜiK (2012) Gelir ve Yaşam Koşulları Araştırması. TÜiK: Ankara.

ul Haq, M. (1995) Reflections on Human Development. N.Y.: Oxford University Press.

UNDP (1990) Human Development Report 1990. New York: Oxford University Press.

van Praag, B.M.S. (1971) "The Welfare Function of Income in Belgium: An Empirical Investigation" European Economic Review, 2, 337-69. van Praag, B.M.S. ve Kapteyn, A. (1973) "Further Evidence on the Individual Welfare Function of Income: An Empirical Investigation in the Netherlands" European Economic Review, 4: 33-62.

van Praag, B. M., Frijters, P. ve Ferrer-i-Carbonell, A. (2003) "The Anatomy of Subjective Well-being" Journal of Economic Behavior \& Organization, 51(1):29-49.

Veenhoven, R. (1984) The Concept of Happiness, In R. Veenhoven (ed.), Conditions of Happiness (pp. 1238). Springer: Dordrecht.

Veenhoven, R. (2000) "The Four Qualities of Life” Journal of Happiness Studies, 1(1), 1-39.

Veenhoven, R. (2008) "Sociological Theories of Subjective Wellbeing", In Michael Eid \& Randy Larsen (Eds). The Science of Subjective Well-being: A tribute to Ed Diener (pp. 44-61), Guilford Publications, New York.

Walelign, S. Z., Charlery, L., Smith-Hall, C., Chhetri, B. B. K. ve Larsen, H. O. (2016) "Environmental Income Improves Household-Level Poverty Assessments and Dynamics" Forest Policy and Economics, 71:2335.

World Bank (1990) World Development Report 1990: Poverty. New York: OUP. 